\title{
Interactive Effects of Stoicism and Religious Coping on Psychological Distress, Fatigue and Intercultural Communication: Muslim Health Workers in Bali
}

\author{
A. Akrim ${ }^{1}$, Rudianto, and Abrar Adhani \\ Universitas Muhammadiyah Sumatera Utara, Medan, Indonesia
}

\begin{abstract}
The rapid transmission of Covid-19 posed threats and challenges for people all around the world. Based on self-ownership theory, the current study tested the interactive effect of positive religious coping and stoicism in decreasing psychological distress and physical fatigue and increasing intercultural communication among Muslim health workers. This study advances the body of literature regarding coping mechanisms in the form of stoic believes and religion to decrease the stressors during disastrous situations like the COVID19. Using a longitudinal field survey, data were collected from 243 Muslim health workers performing their duties at various public and private hospitals and medical centers in Bali, Indonesia. Data were analyzed using SmartPLS software. The results revealed that interactive effects of positive religious coping with stoicism helped decrease psychological stress and physical fatigue and increase intercultural communication among Muslim health workers during Covid-19. The study contributed to the body of knowledge regarding the role of religious practices and stoicism in building coping mechanisms among Muslim health workers to sustain themselves in a challenging environment.
\end{abstract}

Keywords: Bali, intercultural communication, Muslim health workers, physical fatigue, psychological distress, self-ownership theory.

Bali is a popular tourist spot, and, as the Covid-19 pandemic affected Indonesia, Bali was considered a prime spot for the spread of the virus due to national and international visitors (Djalante et al., 2020). Instead, Bali became a role model for tackling the pandemic. According to Governor Wayan Koster, the success in curbing the virus has come with the help of about 1500 traditional village committees with considerable sway over the majority of Muslim residents (Mediastari, 2020). The fatality rate was $1.2 \%$, far below the $6.5 \%$ rate for the rest of the country (Zhang et al., 2020).

In looking at reasons for this difference, this study explores Bali Muslim health workers' role in controlling the spread of the virus while exhibiting stoicism because religion is thought to be an important factor while fighting disastrous situations. Moreover, Muslim health workers play a vital role in dealing with the virus, recovery, and increasing awareness among the population (Mayer \& Lewis, 2020). Although previous studies have presented various theories to support Bali's resistance to the spread of the virus (Bhaskara \& Filimonau, 2021), very few have explored religion and health workers' roles in coping with the virus in crises scenario. Therefore, this study is unique in exploring and highlighting the current fact about the interactive effect of stoicism and positive religious coping on health workers' various psychological and physical emotions and states concerning the Covid-19 scenario.

${ }^{1}$ Corresponding Author E-Mail: akrim@umsu.ac.id 
Stoicism is a philosophy of personal ethics, informed by a system of logic and views on the natural world (Hill \& Nidumolu, 2020). It teaches the development of self-control and fortitude in dealing with harmful thoughts and actions (Huecker, 2020) and is based on maximizing positive emotions while reducing negativity to enhance the self-virtue of an individual. Moreover, Kaukiainen and Kõlves (2020) stated that stoicism is based on a law of nature, which says that everything happens for a reason, whether good or bad. It concentrates on a positive outlook and mental strength on various stressors, uncertainty, and unwanted things in one's life. Stoicism has four virtues: courage, wisdom, justice, and moderation, grounded in the belief that an individual reacts based on his judgment towards a particular event in his life (Táíwò, 2020). Stoicism has been studied in Buddhism religious context (Táíwò, 2020). In contrast, this study explores it in terms of Muslim health workers' physical and psychological states, which have not been investigated previously in the literature for Muslimism beliefs.

Positive religious coping has been associated with a reappraisal of stressors, seeking spiritual support from God to deal with challenges occurring in one's life (French et al., 2020). Positive religious coping has also been associated with improving individuals' psychological wellbeing (Pandey \& Singh, 2019). It is conceptualized in how one copes with uncertainty and psychological stressors by using and approaching religion in terms of prayers and practicing religion (Thomas \& Barbato, 2020). Literature shows that stoicism deals with coping strategies for positive psychological growth (Kaukiainen \& Kõlves, 2020). Hence, investigating how positive religious coping interacts with stoicism to decrease the intensity of an individual's negative feelings and physical exertions and increase the frequency of the positive behaviors in extreme environmental conditions such as Covid-19 is of utmost significance.

Additionally, this study explores stoicism's impacts on psychological distress. It is related to a state of emotional suffering due to frustration and a lack of effective care (Qiu et al., 2020). Today's lifestyle poses many challenges for people's mental health; these challenges include deadlines, workload, materialistic life standards, and lack of physical activity (Dengechi et al., 2021). Covid-19 also has created much psychological distress for people worldwide in terms of anxiety, personal loss due to death, physical inability, and fear of loss of job opportunity and businesses (Li et al., 2020; Mansoor, 2021a). This study highlights the role of stoicism and its impact on psychological distress to deal with the virus crises situation.

In addition to psychological issues, today's lifestyles and Covid-19 have physiological impacts on people (Sueca et al., 2021). One such adverse impact is fatigue. Fatigue is related to feelings of tiredness and low energy levels exhibited by the body to perform daily activities (Maman et al., 2020). It is associated with the body facing physical hardships to endure physical competitiveness to accomplish various tasks (Rahiem \& Rahim, 2020). It occurs due to physical exertion beyond an individual's capability and capacity due to exposure to stress (Taylor et al., 2019). Hence this study makes an advance by analyzing how stoicism can help deal with the physical fatigue of individuals.

Finally, another important construct explored in this study is intercultural communication, which is the communication between people from different cultures (Sastry \& Ramasubramanian, 2020). It is a symbolic, interpretive, transactional, contextual process in which people from different cultures create shared meanings (Ramos-Roure et al., 2021). It has long been linked in the literature to employees and their bargaining agreements while interacting with employees from different cultural backgrounds (Putra et al., 2021). It has also been studied in an educational context where students from different cultures interact to enhance learning capabilities (Makhmudov, 2020). But very few studies have focused on intercultural communication in terms of stoicism to 
deal with a positive outlook and coping mechanisms. Therefore, this study contributes to the literature by exploring the strength of intercultural communication based on the interactive effect of positive religious coping and Stoicism among Muslim health works during the pandemic times.

The current study uses self-ownership theory, which has not been highlighted much in the literature regarding stoicism and positive religious coping regardless of a strong link between stoicism and self-ownership theory (Foroutan, 2019). This theory advocates sovereignty of one's own body and life, which is also related to the concept of stoicism (Hill \& Nidumolu, 2020). Stoicism supports self-oikeiosis and proprioception; these ideas brought forward the selfawareness, consciousness, integration, and individuation that enabled a conception of individual personhood and self-ownership (Shanks, 2019), further leading to a decrease in the negative feelings and an increase in positive attitudes and behaviors. Hence current study is rooted in selfownership theory to answer the following questions;

- Does stoicism impact psychological distress, physical fatigue, and intercultural communication among Muslim health workers in Bali concerning Covid-19?

- Does positive religious coping interact with stoicism to decrease the psychological distress, physical fatigue, and intercultural communication among Muslim health works in Bali concerning Covid-19?

\section{Literature Review and Theoretical Foundation of the Study}

\section{Theoretical Foundation}

The current study is grounded in the self-ownership theory proposed by John Locke, an English philosopher who advocated the idea of "property in the person" (Hill \& Nidumolu, 2020, pp. 18). His ideas can be linked to ancient Stoics' belief that every individual deserves moral equality and self-perseverance (Cossette-Lefebvre, 2020). Stoics believe that people's safeguarding of their rights is the underlying concept of self-ownership. The concept advocates that people act to the best of their judgment and knowledge so that their actions can be rational under various circumstances (Corboy et al., 2019). Moreover, self-ownership has been linked to moral and intellectual autonomy, supporting Stoics' beliefs in virtue, wisdom, and duty (Cohen \& Cohen, 1995). It has been linked with labor law and the right to property ownership to everyone in earlier concepts (Angebauer, 2020).

The strongest link between Stoicism and self-ownership theory is the concept of Oikeiosis, which is a term used by Stoics that translates as appropriation, affiliation, and familiarization (Kaukiainen \& Kõlves, 2020). It supports the belief that one belongs to oneself, creating the notion of self-preservation (Pathak et al., 2017). This is supported through the belief that taking care of ourselves and our interests is a priority. This study explores how self-ownership can elaborate an understanding of stoicism to reduce feelings of distress and fatigue and increase the intercultural communication among Bali's Muslim health workers during the pandemic. This perseverance, selfconcept, and religious Muslimism beliefs are expected to play a coping role in mitigating the negative outcomes of situational phenomena such as Covid-19. 


\section{Relationship between Stoicism and Psychological Distress, Physical Fatigue and Intercultural Communication}

Stoicism's philosophy is often divided into three parts, i.e., logic, physics, and ethics (Táíwò, 2020). It is believed that one should lead their life and encounter external factors to maximize happiness and virtue (Scoats \& Robinson, 2020). Currently, it is being incorporated in modern studies to build guiding principles against various challenges individuals face concerning their changing environment (Kaukiainen \& Kõlves, 2020). Also, stoicism is an attractive philosophy for mental well-being, as it approaches differences in the mind through mediation and self-transformation. It can negate feelings of anguish and distress in a person's inner self. Because Stoics strongly believe in positive thinking, they can counter the negative emotions within a person by focusing on energy and thoughts towards self-virtue (Sharma \& Singh, 2019).

Psychological distress is caused by various traumatic events and a person's inability to cope with stressors effectively. Such can lead to difficulty in anger management, compulsive behavior, and mood swings (Li et al., 2020), which is related to loss of empathy in interpersonal relationships and, in turn, related to loss of productivity. Studies show that stoicism can eradicate distress by persistently and optimistically embracing self-awareness (Lo, 2012; McAteer \& Gillanders, 2019). Therefore, this study argues that individuals with high stoicism may have decreased levels of psychological distress in a person compared to others. Thus, it is hypothesized that.

\section{H1: Stoicism is negatively associated with health workers' psychological distress.}

Stoics believe physical exertion builds up the body's immunity and temperament against physical illness (Huecker, 2020). Stoicism supports physical education to improve the physical powers of individuals. It advocates mental and physical development to overcome obstacles in the environment (Missel et al., 2020). It also encourages the mind to be trained by imagining the worst possible physical scenario and preparing the body and mind to tackle that scenario successfully. Moreover, it is based on the practice of Premeditation Malorum (the pre-mediation of evils), which allows an individual to imagine misfortune and visualize proper response against it, thereby increasing chances of success (Pathak et al., 2017).

Physical fatigue can be caused due to several factors in one's environment, including medical condition, stress, and unhealthy lifestyle (Al et al., 2006). Studies show that an unfit and unhealthy person can easily get tired and feel fatigued, but training the body through proper exercise can increase the body's endurance and ability to overcome the physical challenges of an illness (Al et al., 2006; Maman et al., 2020). Literature supports that Stoic belief in all human actions focused on acquiring happiness, which can eliminate feelings of displeasure, stress, and tiredness in an individual (Jordan, 2020). Therefore, this study argues that stoicism can reduce health workers' fatigue by providing them with a sense of accomplishment in their work and motivation for physical exertion amid challenging times of Covid-19. Thus, it is hypothesized that;

\section{H2: Stoicism is negatively associated with health workers'physical fatigue.}

Stoics believe in self-fulfillment through trying to control perceptions and feelings subjective to what is happening in the external environment (Hodge, 2018). People believe in changing whatever is unsatisfactory in their life, and if they cannot change it, they should embrace 
it but should not complain about it (Pathak et al., 2017). Stoicism supports the law of nature, as everything has a reason and purpose to happen in one's life, whether good or bad. Research has found that stoicism strongly believes in dignity, stability, fortitude, and courage by working on one's skills and abilities (Missel et al., 2020; Sawatsuk et al., 2018). Stoicism advocates taking responsibility for actions rather than complaining.

Previous literature supports that stoicism can enhance positive outcomes based on the selfbelief of the individuals (Smrcz, 2017). However, the literature lacks evidence for intercultural communication and its relation to stoicism. Besides, the organizational climate and employee motivation have been positively associated with intercultural communication (Foroutan, 2019; Putra et al., 2021; Akrim \& Gunawan, 2021). Moreover, Bosuwon (2017) likened social intelligence and competence with interpersonal communication among the students studying in different disciplines. Based on the theory of self-ownership, which supports that an individual is an owner of body and soul, whatever happens to it (Ahmadi, 2021; Baharuddin \& Dalle, 2019; Cossette-Lefebvre, 2020), a Stoic individual can promote a friendly and caring environment and engage in positive behaviors that can further promote intercultural communication by developing positive thoughts among the individuals belonging to different cultures and religious backgrounds. Thus, it is hypothesized that;

\section{H3: Stoicism is positively associated with health workers' intercultural communication.}

\section{The Moderating Role of Positive Religious Coping between the Association of Stoicism with Psychological Distress, Physical Fatigue, and Intercultural Communication}

Positive religious coping has been linked to generating positive psychological outcomes concerning stress, anxiety, and uncertainty (Cornish et al., 2017). It also arouses feelings of emotional comfort and a sense of purpose in life. Seeking spiritual support helps overcome traumatic situations that an individual faces (French et al., 2020). Religion provides hope and faith to followers that better days are coming, providing emotional stability in their lives (McElroyHeltzel et al., 2018). Moreover, in a study related to positive religious coping, Thomas and Barbato (2020) argued that various religious beliefs like Muslimism, Christianity, Buddhism, and Islam played an important role in relaxing and relieving stress during the Covid-19 pandemic, resulting in improved mental well-being. Likewise, Ahmad et al.'s (2020) study of the Muslim community in India revealed that anxiety among those individuals with more religious beliefs and practicing religion was less than those with lower religious beliefs. They also said that strong religious believers enjoyed better psychological well-being than others.

Stoicism is based on the belief that gratitude is earned by positive thinking and regulating one's action following the law of nature (Warbinton, 2019). Stoicism promotes a positive outlook, wisdom, and courage in life, which provides an individual with resourcefulness. Stoics believe in universal reason and exhibiting mindful practices and value-based living (Hysa, 2020; Luczak \& Kalbag, 2018). They also strongly believe in minimizing negative emotions in life by showing joy and gratitude, therefore overcoming distress (Bhui et al., 2008; Liu, 2019; Sadeghi et al., 2018). However, the literature lacks evidence for investigating the interactive effect of positive religious coping with stoicism to minimize individuals' psychological distress. Therefore, in today's modern world, incorporating stoicism with religious beliefs to serve as coping mechanisms for dealing with health workers' distress is an interesting area to explore. Hence, this study argues that the 
interaction of stoicism and positive religious coping is expected to help overcome the psychological distress caused by the Covid-19 scenario. Hence, the following hypothesis is posited;

H4: Positive religious coping moderates the association between stoicism and psychological distress among the health workers such that the higher values of positive religious coping will result in less psychological distress among health workers.

Stoicism believes that the pursuit of pleasure is a necessary part of all worship and virtue (Lo, 2012). Religion has been linked to the spiritual healing of mind and body in prayers, fasting, and seeking spiritual support (Denney \& Aten, 2020). Piousness in religion is achieved by avoiding negative acts that negatively impact society (Manierre et al., 2020). Religious coping also results in a healthy lifestyle through mediation, yoga, prayers, and spiritual retreats where one can spend time in peace, quiet, and rest to observe solitude with God (Pandey \& Singh, 2019). Studies have shown that the religious practices associated with different religions result in mental and physical well-being (Ahmad et al., 2020; Thomas \& Barbato, 2020). Likewise, stoicism also supports the belief of protecting the body from harmful illness and other stressors through exercise, a healthy diet, and virtue practice. Using physical strength to gain a maximum positive outcome for oneself and the environment is an underlying belief of Stoicism (Taylor et al., 2019).

Physical fatigue is a tiredness state arising from a continuous excursion, non-stop work, or any uncertain situation that can be reduced through proper diet, time management, and building physical endurance (Maman et al., 2020). Thus, the current study examines the coupled effect of positive religious coping and stoicism in reducing physical fatigue among the Muslim health workers during the Covid-19 pandemic, which has not been studied before in literature. Moreover, self-ownership theory also advocates taking body autonomy and being responsible for its wellbeing by taking precautions and practicing certain rituals regularly to help the body stay healthy (Quigley, 2018). These precautions and practices can minimize physical fatigue by incorporating religious practices that bring peace and harmony to individuals and promote wellness and avoid tiredness and illness. Hence, this study argues that physical attributes associated with religious practices and religious coping are expected to interact with stoicism to help people in decreasing psychological and physical fatigue due to the Covid-19 scenario. Thus, it is hypothesized that;

H5: Positive religious coping moderates the association between stoicism and physical fatigue among the health workers such that the higher values of positive religious copying will result in less physical fatigue among health workers.

Positive religious coping strengthens faith in positive outcomes (Yamamori, 2019). Whereas stoicism strongly advocates the virtue of justice and following the moral-ethical codes leading a life (Silver, 2017). A virtuous life is free of all passions, which are intrinsically disturbing and harmful to the soul, but includes appropriate emotive responses conditioned by rational understanding and fulfilling all one's personal, social, professional, and civic responsibilities (Dalle \& Hastuti, 2020; Sharma \& Singh, 2019). These beliefs are also in line with various religious teachings and value systems, i.e., the Muslim religion teaches rightfulness, fulfilling one's moralethical duties towards each other and their community (Singaram \& Saradaprabhananda, 2020); therefore, this can eradicate unfair practices from society. Researchers argue that this is a more 
virtual and perfect view of society, and no society can be without misfortune, misery, and other challenges and ill practices (Nedal \& Alcoriza, 2018; Singaram \& Saradaprabhananda, 2020). However, individuals can work together based on Stoicism principles and practice religious obligations to achieve harmony and justice through wisdom and moderation.

Intercultural communication in a multicultural situation may give rise to a communication pattern mutually understood by all participants (Olebe \& Koester, 1989). In their study, Liu (2019) reported that various psychological variables impact intercultural communication among individuals in achieving an environment of mutual understanding. However, to the best of the authors' knowledge, no study has examined the direct or interactive effect of stoicism and religious coping in promoting intercultural communication among individuals in general and health workers specifically. Therefore, this study seeks to bridge this gap in the literature based on the theory of self-ownership. The theory postulates that a balance and precautionary way of living with a blend of religious practices and positive beliefs may enhance a culture of care and concern in society during the Covid-19 pandemic. Thus, it is hypothesized that;

H6: Positive religious coping moderates the association between stoicism and intercultural communication among the health workers such that the higher values of positive religious coping will result in a higher level of intercultural communication among health workers.

\section{Theoretical Framework of the Study}

Figure 1

Theoretical Framework of the Study

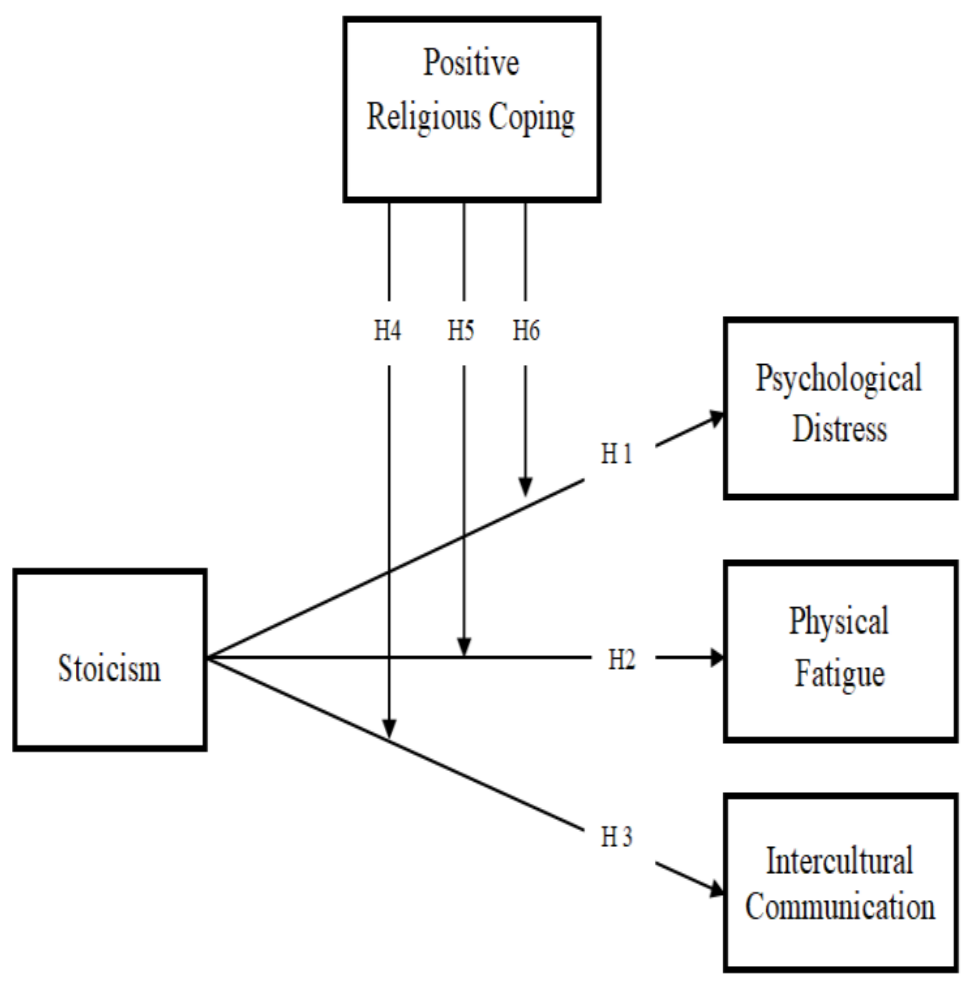




\section{Research Methods}

The study's main objective was to find out the interactive impact of positive religious coping and stoicism in decreasing psychological stress and physical fatigue and enhancing intercultural communication among the Muslim health workers while performing their duties during crises times of Covid-19. Because responsibilities were shifted to the health workers, they had to work without breaks. Bali Muslim health workers' case was chosen because statistics represent that the death and infection rate of the virus was much less in Bali than in other regions of Indonesia (Dalle et al., 2020a; Katipana et al., 2021). In no small measure, the lower rates reflect the dedication and non-stop hard work of the health workers in Bali, Indonesia. Since the eruption of COVID-19, Muslim health workers in Bali continuously remained active to convey the government's response and measures to protect the citizens and mitigate the impact of Coronavirus (Yanti et al., 2021). An online survey was conducted using a quantitative research design to gather data from Muslim health workers. The Bali medical association was contacted to obtain consent for conducting this research among the health workers. After the consent, the Association was requested to introduce the study authors to the management of the 15 targeted medical centers and hospitals.

The management of three hospitals and five medical centers agreed to cooperate and allowed the authors to collect data. Those who agreed provided Muslim health workers' contact information performing their duties in different medical centers and hospitals. The health workers who belong to other beliefs were ignored and not targeted in this study; once receiving the contact information, all health workers were contacted using social media contacts and emails. They were explained about the study's purpose, and strict anonymity of their responses was also ensured to get their voluntary willingness to participate in the study. Those who agreed to participate were further asked for their proficiency in the English language and only those who were considered good at reading and understanding English. This study adapted original scales in English with good, reported reliability, so an English proficiency check was vital before sending the survey to participants. Three hundred forty-seven front-line health workers, including doctors, nurses, and paramedical staff, agreed to participate and qualified for the English proficiency criteria.

Physical contact was avoided due to Covid -19 , so two online surveys were designed. The first survey included demographic information and statements about stoicism plus positive religious coping variables. It was circulated among all candidates via email at Time 1 from October 10, 2020. Of the 347 participants, 315 returned the survey. Of these, 07 responses were partially filled and were excluded from the sample, and the study left with 308 actual useable responses. In Time 2, on December 15, 2020, the second part of the survey was sent to the same 308 participants, which included psychological distress, physical fatigue, and intercultural communication items. A total of 271 respondents filled the second part of the questionnaire and returned it to the study authors. After careful screening, it was found that 17 responses had missing values, and 11 were unengaged; therefore, they were not included in further analysis. Thus, in total, 243 responses that have complete Time 1 and Time 2 data filled were considered as a final response for this study with a response rate of $70 \%$. 


\section{Measures of Study}

The Liverpool Stoicism Scale (LSS), consisting of 20-items adapted from Wagstaff and Rowledge (1995), was used to access the Muslim health workers' stoicism. This scale also includes the ten reverse coded items to avoid the response bias. Positive religious coping was measured by 10-items from two subscales of RCOPE Pargament et al. (2000), which Pandey and Singh (2019) used with well-reported reliabilities. To measure Psychological distress, 5-items adapted from (Long et al., 2020) were used with a self-reported questionnaire where responses were recorded on a 5 -point Likert scale $(1=$ strongly disagree to $5=$ strongly agree). Physical fatigue was measured with 14-self reported items adapted from Chalder et al. (1993). Responses were recorded on 5 point scale with $1=$ absence $5=$ strong presence. Finally, intercultural communication was measured with an 8-item scale adapted from Olebe and Koester (1989).

\section{Demographic Characteristics of the Respondents}

The respondents' demographic characteristics showed that $59.7 \%$ of respondents were male, $41.3 \%$ were females, $53.5 \%$ were married, whereas $46.5 \%$ were unmarried. Results also showed that of the 243 participants, 65 were doctors, 102 were nurses, and 76 were other paramedical staff, including technicians, Diagnostic Medical Sonographers, and therapists. Participants' ages ranged from 21 to 67 years, with a mean of 37.21 years $(S D=7.21)$. The respondents belong to different departments with different specializations. Of the respondents, $86.9 \%$ of respondents stated that during Covid-19, they had been performing their medical duties for more than 16 hours continuously in a day. Most participants $(87.5 \%)$ said that they practiced religious obligations daily, thus providing evidence that the targeted sample matched the religious concept of the theoretical framework.

\section{Data Analysis and Results}

This study used the SmartPLS to perform structural equation modeling (SEM) analysis. Before empirically investigating the hypothesized links, an Analysis of Variance (ANOVA) was conducted to identify the impact (if any) of the respondents' demographic characteristics on the dependent variable. The ANOVA results revealed that none of the demographic constructs affected the dependent variable significantly. Thus, no demographic construct was controlled during further analysis.

\section{Assessing the Measurement Model}

Confirmatory factor analysis was conducted by using SmartPLS3 to investigate the psychometric properties of the measures. Cronbach's alpha and Composite Reliability (CR) were calculated to assess the reliability of measures as per the directions Henseler et al. (2009). Table 1 shows the reliability of all the reflective measures based on Cronbach's $\alpha$ (above 0.70) and CR values. Besides, the measure's convergent and discriminant validity was assessed. For stoicism and two items, i.e., ST8 and ST11, and for physical fatigue, two items, i.e., PF3 and PF12 with factor loadings less than 0.5, were excluded from the analysis as per instructions of Hair et al. (2012) based on their high impact on AVE and the reliability of the whole construct (Mansoor, 2021b). As the factor loadings of all other indicator variables were in the range with a significant loading of 
each item $(p<0.001)$ onto its underlying variable and the AVE of latent variables was above 0.50 for all study constructs, convergent validity was established (Hair et al., 2010; Noor et al., 2021).

\section{Table 1}

Factor Loadings, Reliability, and Validity

\begin{tabular}{|c|c|c|c|c|c|c|c|}
\hline Constructs/Indicators & Factor & oading & & & AVE & $\mathrm{CR}$ & Cronbach's $\alpha$ \\
\hline & 1 & 2 & 3 & 4 & & & \\
\hline Stoicism & & & & & 0.501 & 0.962 & 0.837 \\
\hline ST1 & 0.748 & & & & & & \\
\hline ST2 & 0.727 & & & & & & \\
\hline ST3 & 0.778 & & & & & & \\
\hline ST4 & 0.773 & & & & & & \\
\hline ST5 & 0.819 & & & & & & \\
\hline ST6 & 0.806 & & & & & & \\
\hline ST7 & 0.721 & & & & & & \\
\hline ST9 & 0.737 & & & & & & \\
\hline ST10 & 0.796 & & & & & & \\
\hline ST12 & 0.783 & & & & & & \\
\hline ST13 & 0.821 & & & & & & \\
\hline ST14 & 0.728 & & & & & & \\
\hline ST15 & 0.719 & & & & & & \\
\hline ST16 & 0.840 & & & & & & \\
\hline ST17 & 0.798 & & & & & & \\
\hline ST18 & 0.748 & & & & & & \\
\hline ST19 & 0.723 & & & & & & \\
\hline ST20 & 0.750 & & & & & & \\
\hline $\begin{array}{ll}\text { Positive } & \text { Religious } \\
\text { Coping } & \end{array}$ & & & & & 0.575 & 0.931 & 0.811 \\
\hline PRC1 & & 0.710 & & & & & \\
\hline PRC2 & & 0.708 & & & & & \\
\hline PRC3 & & 0.793 & & & & & \\
\hline PRC4 & & 0.841 & & & & & \\
\hline PRC5 & & 0.731 & & & & & \\
\hline PRC6 & & 0.756 & & & & & \\
\hline PRC7 & & 0.754 & & & & & \\
\hline PRC8 & & 0.820 & & & & & \\
\hline PRC9 & & 0.719 & & & & & \\
\hline PRC10 & & 0.736 & & & & & \\
\hline Psychological Distress & & & & & 0.587 & 0.876 & 0.796 \\
\hline PD1 & & & 0.796 & & & & \\
\hline PD2 & & & 0.775 & & & & \\
\hline PD3 & & & 0.782 & & & & \\
\hline PD4 & & & 0.722 & & & & \\
\hline & & & 223 & & & & \\
\hline
\end{tabular}




\begin{tabular}{|c|c|c|c|c|c|}
\hline PD5 & 0.753 & & & & \\
\hline Physical Fatigue & & & 0.642 & 0.932 & 0.791 \\
\hline PF1 & 0.672 & & & & \\
\hline PF2 & 0.770 & & & & \\
\hline PF4 & 0.745 & & & & \\
\hline PF5 & 0.714 & & & & \\
\hline PF6 & 0.769 & & & & \\
\hline PF7 & 0.758 & & & & \\
\hline PF8 & 0.697 & & & & \\
\hline PF9 & 0.762 & & & & \\
\hline PF10 & 0.770 & & & & \\
\hline PF11 & 0.739 & & & & \\
\hline PF13 & 0.727 & & & & \\
\hline PF14 & 0.638 & & & & \\
\hline $\begin{array}{l}\text { Intercultural } \\
\text { Communication }\end{array}$ & & & 0.531 & 0.900 & 0.808 \\
\hline ICC1 & & 0.717 & & & \\
\hline ICC2 & & 0.712 & & & \\
\hline ICC3 & & 0.794 & & & \\
\hline ICC4 & & 0.670 & & & \\
\hline ICC5 & & 0.756 & & & \\
\hline ICC6 & & 0.736 & & & \\
\hline ICC7 & & 0.782 & & & \\
\hline ICC 8 & & 0.651 & & & \\
\hline
\end{tabular}

Note: $\mathrm{CR}=$ composite reliability; $\mathrm{AVE}=$ average variance extracted.

\section{Discriminant Validity}

Henseler, Ringle, and Sarstedt (2015) suggested that Heterotrait-Monotrait (HTMT) ratio is a more accurate measure of discriminant validity while using smart PLS (Mansoor \& Noor, 2019). The HTMT ratio value should be less than 0.9. As Table 2 shows, all values were less than 0.9 for the entire model.

Table 2

Heterotrait-Monotrait Ratio

\begin{tabular}{llllllll}
\hline Constructs & Mean & STD. & 1 & 2 & 3 & 4 & 5 \\
\hline Stoicism & 4.03 & 0.42 & 0.707 & & & & \\
Positive Religious Coping & 3.81 & 0.59 & 0.431 & 0.758 & & & \\
Psychological Distress & 4.11 & 0.39 & 0.501 & 0.511 & 0.766 & & \\
Physical Fatigue & 3.89 & 0.71 & 0.490 & 0.534 & 0.449 & 0.801 & \\
Intercultural communication & 4.08 & 0.47 & 0.623 & 0.477 & 0.454 & 0.329 & 0.728 \\
\hline
\end{tabular}

Note. The square roots of AVEs of the constructs are shown in bold in diagonal. 
Figure 2

Full Measurement Model

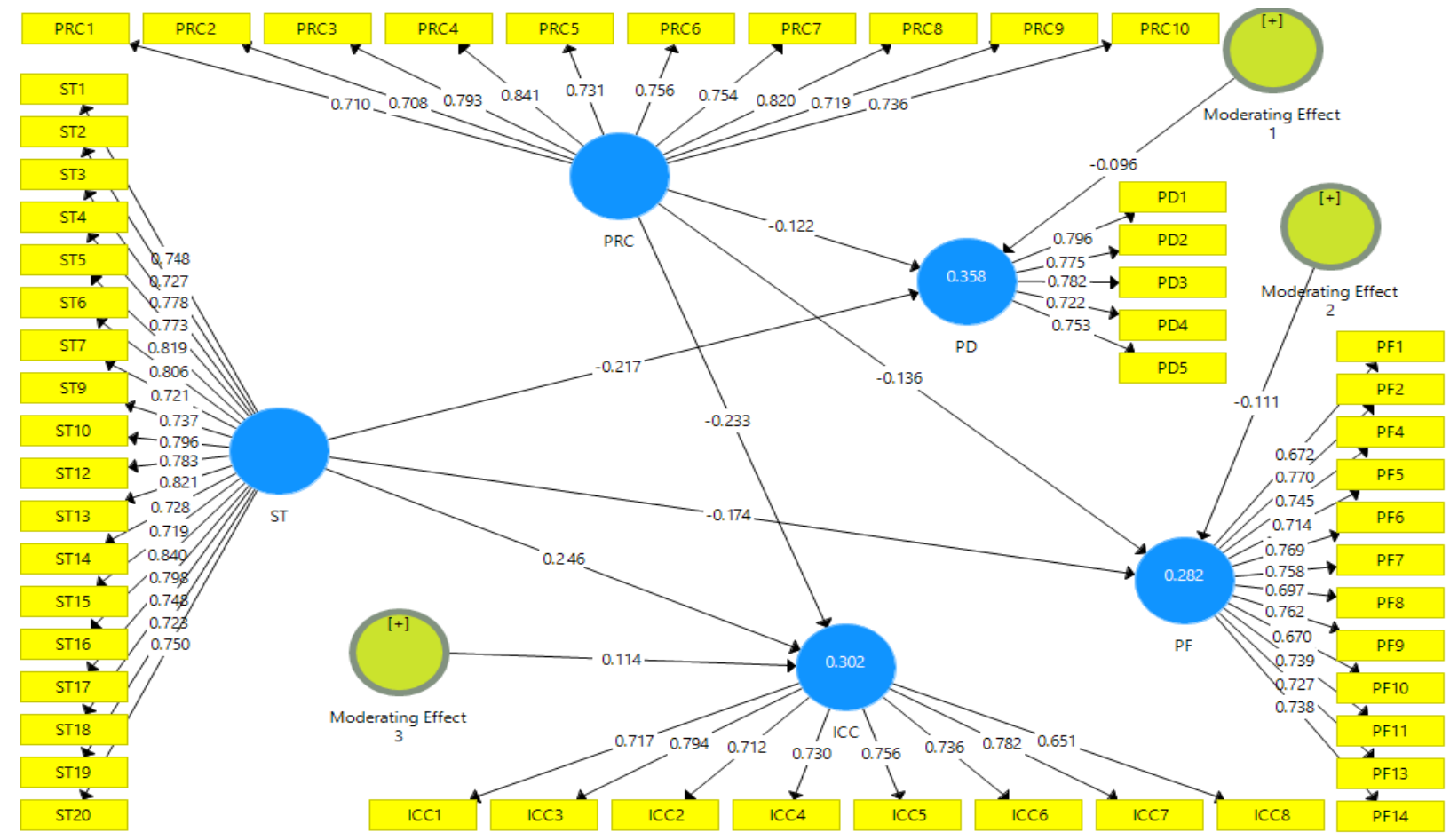

\section{Assessing the Structural Model}

\section{Direct Hypothesis}

The results in Table 3 show a negative and significant relationship of Stoicism with psychological distress $\left(\beta=-0.217^{* *}, \mathrm{t}=5.203\right)$, physical fatigue $(\beta=-0.174 * * *, \mathrm{t}=4.301)$. whereas results depicted a positive and significant association of stoicism with intercultural communication $\left(ß=0.246^{* * *}, \mathrm{t}=6.390\right)$. Therefore, $\mathrm{H} 1, \mathrm{H} 2$, and $\mathrm{H} 3$ are fully supported by the study results.

\section{Moderating Hypotheses}

To assess the moderating effect of a construct in PLS-SEM, interaction terms between the moderator, positive religious coping, and predictor stoicism were created using the product indicator approach to examine its effect on psychological distress, physical fatigue, and intercultural communication among the Muslim health workers during Covid-19 scenario. The results indicated in Table 3, shows significant effect of interaction terms, positive religious coping*Stoicism on psychological distress $\left(\beta=-0.096^{* *}, t=2.934\right)$, physical fatigue $(\beta=-$ $0.111 * *, t=3.115$, and intercultural communication $(\beta=-0.114, t=3.288)$.

The R2 change between the main effect model and the model with moderation effect was also examined following the moderation result. The $R^{2}$ for Stoicism's main effect on psychological distress was $\left(R^{2}=0.237\right)$, whereas its $R^{2}$ with positive religious coping moderating effect increased to $\left(R^{2}=0.358\right)$. The $R^{2}$ change suggested that the inclusion of an interaction term increased the explanatory power of decreasing psychological distress among Muslim health workers by $12.10 \%$; 
likewise, including an interaction term increased the explanatory power of decreasing physical fatigue and increasing intercultural communication among Muslim health workers was by $13.26 \%$ and $13.67 \%$ respectively. Moreover, the negative association of the moderator and the dependent variable is explained through plotted moderation graphs. See Figures 3, 4, and 5 below.

\section{Figure 3}

Interaction plots for the moderating effect of Positive Religious Coping in between the Stoicism and Phycological distress relationship

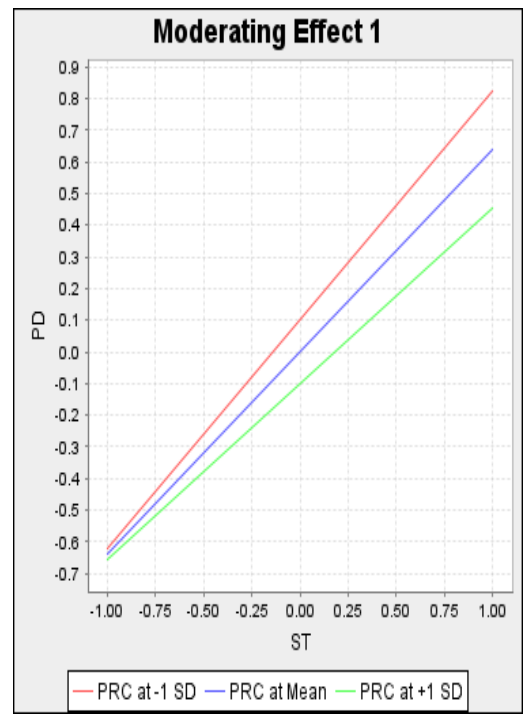

\section{Figure 4}

Interaction plots for the moderating effect of Positive Religious Coping in between the association of stoicism and physical fatigue

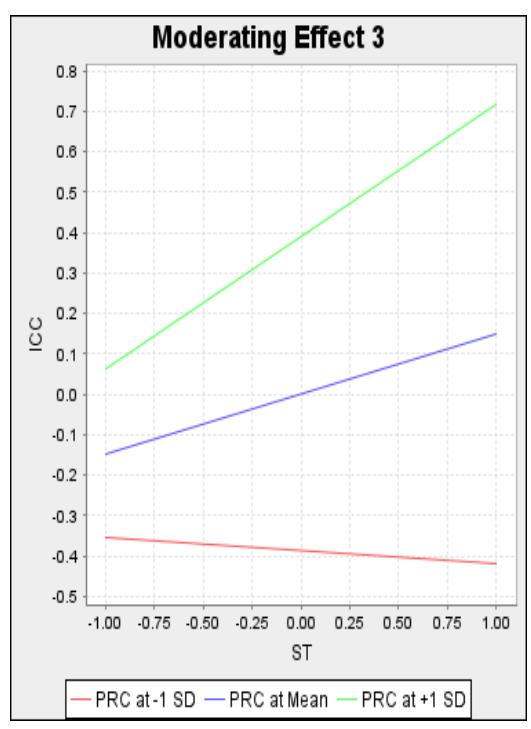

\section{Figure 5}

Interaction plots for the moderating effect of Positive Religious Coping in between the Stoicism and Intercultural communication relationship

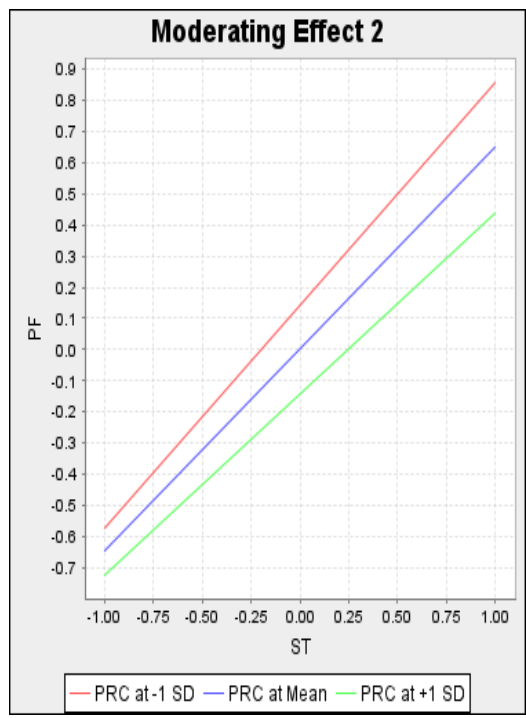

Figure 3 shows similar results as the line labeled for a higher level of positive religious coping had a less steep gradient than the lower level of positive religious coping for the association of stoicism and psychological distress. This demonstrates that the more positive religious coping, the less the psychological distress among the Muslim health workers during the Covid-19 time. Thus, hypothesis 4 was supported.

Figure 4 depicts similar results as the line labeled for a higher level of positive religious coping has a less steep gradient than the lower level of positive religion for the association of stoicism and physical fatigue. This shows that those health workers who believe in and practice religion feel less physical exertion while performing duties for society's welfare. Thus, hypothesis 5 was also supported.

In contrast to the above results, as shown in Figure 5, the line labeled for a higher level of positive religious coping has a steeper gradient than the lower level of positive religious coping for the association of stoicism and intercultural communication, which represents the Muslim health workers satisfaction with the system in the case when they are more religious sort of persons who believe in positivity and religious teachings along with practicing its rituals daily. In such circumstances, they interact more and communicate with their peers and community to serve them positively based on their care and concern for the community. Thus, hypothesis 6 was also supported. Figure 6 presents the full structural model, and Table 3 shows the results of the hypothesis testing. All hypotheses were supported. 
Table 3

Hypothesis Testing Results

\begin{tabular}{llllll}
\hline & Hypotheses & Std. Beta & t-Value & p-values & Findings \\
\hline H1 & ST $\rightarrow$ PD & -0.217 & 5.203 & 0.000 & Supported \\
H2 & ST $\rightarrow$ PF & -0.174 & 4.301 & 0.000 & Supported \\
H3 & ST $\rightarrow$ ICC & 0.246 & 6.390 & 0.000 & Supported \\
H4 & PRC*ST $\rightarrow$ PD & -0.096 & 2.934 & 0.010 & Supported \\
H5 & PRC*ST $\rightarrow$ PF & -0.111 & 3.115 & 0.009 & Supported \\
H6 & PRC*ST $\rightarrow$ ICC & 0.114 & 3.288 & 0.006 & Supported \\
\hline
\end{tabular}

Note. $\mathrm{ST}=$ Stoicism; $\mathrm{PRC}=$ Positive Religious Coping; $\mathrm{PD}=$ Psychological Distress $\mathrm{PF}=\mathrm{Physical}$ Fatigue; ICC $=$ Intercultural communication

Figure 6

Full Structural Model

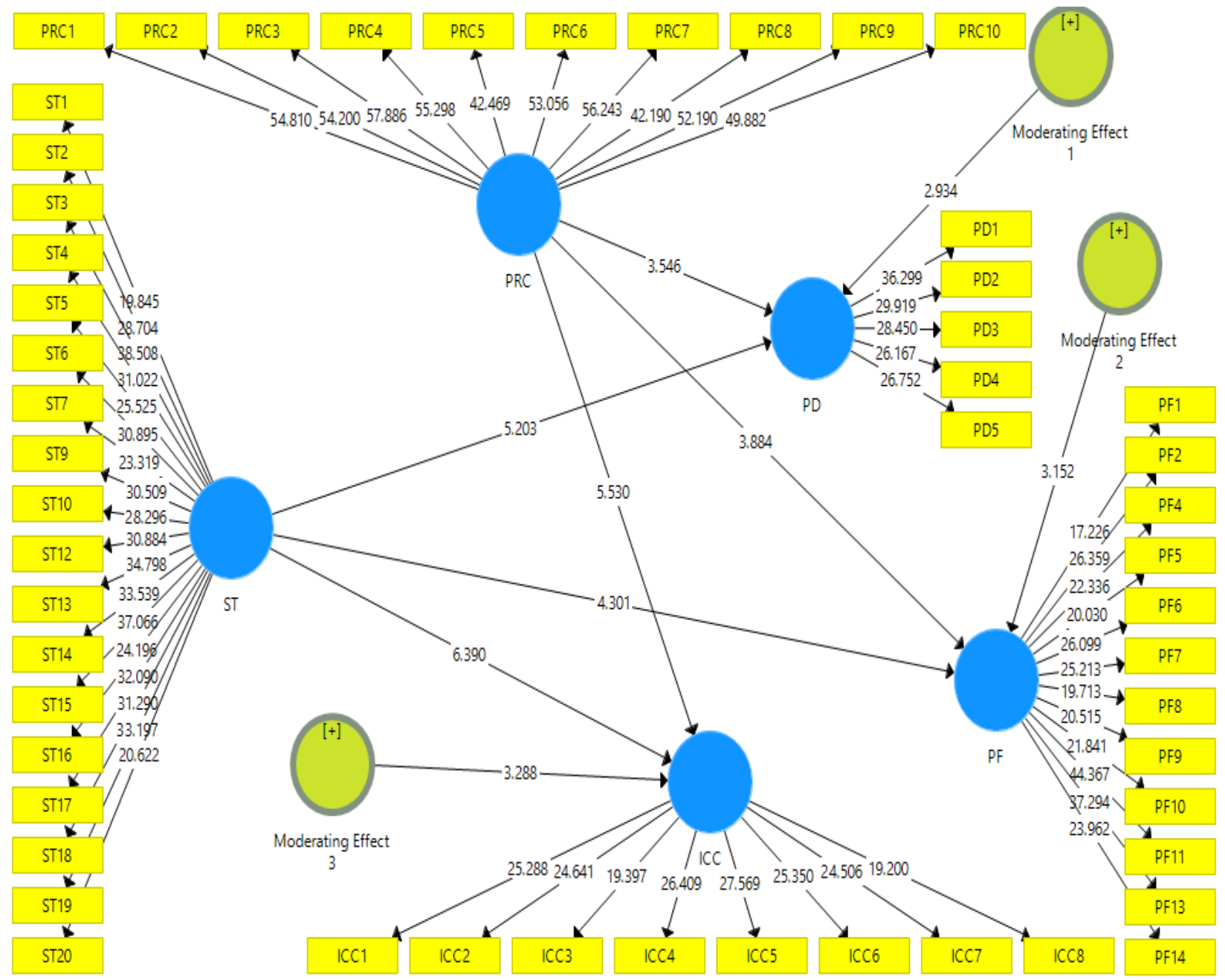




\section{Discussion, Implications, Limitations, and Future Directions}

\section{Findings of the Study}

Grounded on self-ownership theory, this study was conducted to investigate stoicism's role in decreasing the level of psychological distress, physical fatigue and increasing the intercultural communication among the Muslim health workers during the pandemic. The current study was conducted among Muslim health workers in Bali. Although Indonesia has formulated a task force to respond to Covid-19 all over the country, the Muslim community and health workers in Bali played a vital role in combating the virus resulting in a lower death rate in Bali than in the rest of Indonesia.

The study results show that stoicism negatively impacted psychological distress among Muslim health workers during the Covid-19 period. These results align with Sharma and Singh's (2019) findings, who advocated positive thinking among the Stoics, decreasing negative emotions or stressors based on self-confidence and belief. Further, as Stoics believe in positivity and selfreliance, they possess the capability to deal with any worse situation (Dalle et al., 2020b; Táíwò, 2020). The same happened in pandemic times; the health workers with Stoic personality features overcome the psychological distress of being infected; in turn, they remained firm and enthusiastic about saving their people from a deadly virus, which is evident from Bali's low Covid-19 death rates (Katipana et al., 2021). Moreover, results also found a negative and significant association between stoicism with physical fatigue, reflecting that Stoic belief can suppress feelings of stress, tiredness, and exertion (Jordan, 2020). Stoicism motivates individuals to fight and survive any situation, turning tiredness into feelings of achievement and accomplishment.

Simultaneously, the impact of stoicism in increasing intercultural communication among health workers in Bali was demons. This finding can be related to the Putra et al. (2021) and Bosuwon (2017) prepositions, who linked motivation and personal competencies with intercultural communication, respectively. The current findings depict that fortitude, dignity, and stability embedded in one's abilities and skills can encourage him/her to display positive attitudes and behaviors. Thus, based on the results, Stoic persons can utilize their skills and abilities to turn any unusual situation into an environment of helpfulness, mutual trust, and concern by enhancing intercultural communication among the different society players. In addition, the moderating role of positive religious coping between the association of stoicism and psychological distress was demonstrated. The results demonstrated that when positive religious coping interacts with stoicism, it reduces the psychological distress among the Muslim health workers as religious practices bring stability and relaxation among believers (Miconi et al., 2021), which can further decrease the psychological distress. At the same time, stress-free health workers can be a great source for protecting people's lives in the Covid-19 situation.

Positive religious coping and stoicism's interactive effect significantly decreased physical fatigue among Muslim health workers. Others have found much the same. For example, Denney and Aten (2020) and Manierre et al. (2020) linked religious activities like prayers, helping others, and seeking spiritual support to the spiritual healing of mind and body. Likewise, stoicism has been linked to save the body from mental and physical illness (Taylor et al., 2019). Therefore, when these positive constructs interact with each other, they act as a strong coping mechanism to help an individual overcome physical tiredness and work for humanity's benefits, to which believers give more value over anything else.

Finally, the coupled effect of positive religious coping and stoicism was significant in increasing the intercultural communication among the Muslim health workers during Covid-19. 
This result shows that when health workers regularly practice their religious obligations, it makes them more generous towards humanity. Thus, they frequently communicate with their peers regarding different matters; they also interact with the community belonging to different cultural backgrounds to cure deadly diseases. Moreover, studies have shown that Bali's healthcare system is a work in progress and utilizes human resources to meet health demands (Wade et al., 2018). Moreover, during the pandemic, Bali health workers worked to their full capacity and helped the whole nation fight against this lethal virus by going the extra mile. This shows they are deep-rooted in religious norms and values; Muslim beliefs prefer humanity over their physical status and high place in society. Rather they showed dedication and courage to work for their people and defeated the virus through stoicism and positive religious coping by developing higher levels of intercultural communication during Covid-19.

\section{Theoretical Implications}

The current study made an advance by applying self-ownership theory to investigate the impact of stoicism on various psychological stressors and physical fatigue among Muslim health workers aimed Covid-19. Such theoretical investigations are scarce in religious literature, and especially in the crisis of Covid-19, it provided a perfect case to study regarding Muslim Bali health workers. The entire combination of theoretical integration of study factors and study settings is a significant advance to the body of knowledge. There are multiple theoretical contributions to this research.

- First, this is among the earliest studies to consider the case of Indonesian Muslim health workers in the Covid-19 scenario. The study provided unique empirical evidence from Indonesia's multicultural and multi-religious context, advancing to existing literature.

- Second, this is among the earliest studies considering positive religious coping and its role in the Covid-19 scenario to mitigate the negative effects of Covid-19 on health workers. Thus, incorporating the religious construct with stressors and negative outcomes is a major theoretical advance of this research.

- Third, the research on stoicism and negative outcomes is scarce in the existing literature, and very few studies have established the relationships in multicultural and multi-religious settings. Testing these links in crises times is a major theoretical advance of this research.

- Fourth, the impact of stoicism in enhancing the health workers' intercultural communication with the natives is a valuable contribution to the literature.

- Fifth, a gap exists in current literature for studies incorporating religious variables with stoicism. This study attempted to fill this gap by testing the interactive effects of positive religious coping and stoicism in a single study framework. This integration in a single theoretical framework is also a major advance of this research.

- Sixth, research is scarce in this domain for time-lagged studies, so this research advanced the literature by adopting a longitudinal study design for assessing the impact of stoicism and positive religious coping on outcomes.

- Last, this research also advanced the literature and theory related to health workers and their coping mechanisms using religious beliefs and explained how they cope with psychological distress and physical fatigue during crises. 


\section{Practical Implications}

This study offers valuable insights for practitioners and policymakers. For instance;

- The current study was conducted among the health workers in Bali, Indonesia, who faced many issues regarding their education and facilities. Despite these issues, they performed their best to help the nation in the Covid-19 crisis. This research shows that the reason behind this extraordinary performance was religious involvement interacting with constructs such as stoicism. Thus, policymakers may devise strategies to incorporate religious elements while designing motivational packages for the sensitive workforce, such as health workers.

- The current study also shows the importance of stoicism in establishing self-control and managing different stressors and physical fatigue. Thus, health workers must be provided regular training sessions to build positive feelings of self-reliance, confidence, and control over emotions in usual or unusual situations. Thus, policymakers may consider religious counseling as a regular training session to develop stoicism virtues that promote a positive outlook needed to handle stress and challenges in the post-pandemic era.

- Moreover, governments of developed and developing countries can also implement policies regarding stoicism to emphasize ethics as the focus of health workers' knowledge training and development.

- This study is unique in pointing out religious coping as a moderator to decrease psychological stress and physical fatigue and increase intercultural communication among Muslim health workers, proving significant. Hence, ensuring covid 19 health workers' psychological well-being through positive religious coping across the country will help maintain harmony, peace, and unity among fellow country members and lead to their wellbeing.

- Finally, all religions should be allowed to practice their religious rituals more freely by providing them with all facilities. Hence, developed and developing nations' governments and policymakers may also consider the findings of this research to use religious coping as an intervention to motivate the workforce in crises like Covid-19.

\section{Limitations and Future Directions}

Along with many strengths, the current study has certain limitations that can bring valuable insights if overcome in the future. First, this study focused on Muslim health workers investigating psychological and physical stressors while fighting the deadly Covid-19 pandemic with limited resources. In contrast, future studies can explore health workers from different religions and the impact of positive religious coping and stoicism on various stressors. Hence, a comparative study is recommended in a different cultural context to further validate this research's findings. Second, this study investigated the interactive effect of positive religious coping and stoicism in decreasing negative psychological stressors and psychical exertion among Muslim health workers and enhancing intercultural communication among health workers to benefit society. Future studies can explore this interactive effect in generating and enhancing positive psychological and physical outcomes like well-being, performance, engagement, and satisfaction. Finally, the current study relies only on a quantitative technique with self-reported measures. In contrast, future studies can conduct experiments to calculate the physical fatigue and exertion among the health workers to 
check the immediate and long-lasting impact of religious practices on relaxing the body and decreasing the physical exertion among believers of different religions. This research used selfownership theory to explain the interplay between ethical and religious constructs, so future scholars may look for other motivational theories to explain the mechanism through which stoicism is linked with outcomes.

\section{Conclusion}

Since the outbreak of the Covid-19, people worldwide have had to face various psychological and physical stressors (Gates, 2020). Besides, health workers being on the frontline were most affected by the pandemic (Thomas \& Barbato, 2020). Therefore, this study is unique in exploring and highlighting the interactive effect of stoicism and positive religious coping on health workers'various psychological and physical emotions and states concerning the Covid-19 scenario. Moreover, based on self-ownership theory, the current study tested the interactive effect of positive religious coping and stoicism in decreasing psychological distress and physical fatigue and increasing intercultural communication among Muslim health workers. Hence, a longitudinal field survey was conducted to collect data from 243 Muslim health workers performing their duties at various public and private hospitals and medical centers in Bali, Indonesia. Data were analyzed using SmartPLS software. The results revealed that positive religious coping with stoicism's interactive effects helped decrease psychological stress and physical fatigue and increase intercultural communication among Muslim health workers during Covid-19. Moreover, the study contributed to the body of knowledge regarding the role of religious practices and stoicism in building coping mechanisms among Muslim health workers to sustain themselves in a challenging environment. The current study also presents valuable implications and policy insights for the developed and developing nations and suggests future research directions to scholars.

\section{References}

Ahmad, A., Rahman, I., \& Agarwal, M. (2020). Factors influencing mental health during COVID19 outbreak: An exploratory survey among Indian population. Journal of Health Sciences, 10(2), 147-156. https://doi.org/10.17532/jhsci.2020.950

Ahmadi, A. (2021). The traces of oppression and trauma to ethnic minorities in Indonesia who experienced rape on the 12 May 1998 tragedy: A review of literature. Journal of Ethnic and Cultural Studies, 8(2), 126-144. https://doi.org/10.29333/ejecs/744

Akrim, A., \& Gunawan, G. (2021). Quranic storytelling approach as educational model to teach religious values in the indonesian context. Educational Sciences: Theory and Practice, 21(1), 53-67

Al, A. L., Peterson, C., Tice, T. N., Rodgers, W., Seymour, E. M., \& Bolling, S. F. (2006). Differential effects of faith-based coping on physical and mental fatigue in middle-aged and older cardiac patients. The International Journal of Psychiatry in Medicine, 36(3), 351-365. https://doi.org/10.2190/88CC-W73K-0TM4-JX3J

Angebauer, N. (2020). Property and capital in the person: Lockean and neoliberal self-ownership. Constellations, 27(1), 50-62. https://doi.org/10.1111/1467-8675.12424

Baharuddin, B., \& Dalle, J. (2019). Transforming learning spaces for elementary school children with special needs. Journal of Social Studies Education Research, 10(2), 344-365. https://files.eric.ed.gov/fulltext/EJ1220720.pdf 
Bhui, K., King, M., Dein, S., \& O'Connor, W. (2008). Ethnicity and religious coping with mental distress. Journal of Mental Health, 17(2), 141-151. https://doi.org/10.1080/09638230701498408

Quigley, M. (2018). Self-ownership, property rights, and the human body: A legal and philosophical analysis. Cambridge University Press.

Bosuwon, T. (2017). Social intelligence and communication competence: Predictors of students' intercultural sensitivity. English Language Teaching, 10(2), 136-149. https://files.eric.ed.gov/fulltext/EJ1128538.pdf

Chalder, T., Berelowitz, G., Pawlikowska, T., Watts, L., Wessely, S., Wright, D., \& Wallace, E. (1993). Development of a fatigue scale. Journal of Psychosomatic Research, 37(2), 147153. https://doi.org/10.1016/0022-3999(93)90081-P

Cohen, G. A., \& Cohen, G. A. (1995). Self-ownership, freedom, and equality. Cambridge University Press.

Corboy, D., Meier, J., \& McLaren, S. (2019). Self-reliance and stoicism as predictors of distress following radical prostatectomy in the context of place of residence. Psychology of Men Masculinities, 20(4), 637-646. https://doi.org/10.1037/men0000197

Cornish, M. A., Lannin, D. G., Wade, N. G., \& Martinez, M. (2017). Can use of positive religious coping predict greater distress? An examination of army soldiers on deployment. Journal of Counseling Psychology, 64(3), 302-309. https://doi.org/10.1037/cou0000200

Cossette-Lefebvre, É. (2020). Personality, privacy, and property: Trans-systemic perspectives on self-ownership (Publication no. 28093033) [Master's thesis, the University of Toronto]. ProQuest Dissertations Publishing.

Dalle, J., Hairudinor, H., Baharuddin, B., Sriadhi, \& Chandra, T. (2020a). Does it unrest alter the effect of risk-taking attitude on the organization's performance? Journal of Security and Sustainability Issues, 9(5), 158-172. http://doi.org/10.9770/jssi.2020.9.M(13)

Dalle, J., \& Hastuti, D. (2020). Prototype decision support system selecting employee for certain position using profile matching. Journal of Engineering and Applied Sciences, 12(2), 183185. https://doi.org/10.3923/jeasci.2017.171.175

Dalle, J., Siyoto, S., Astika, N. D., Negara, D. J., Chandra, T., \& Anam, K. (2020b). Moderating role of IT adoption and mechanism of dynamic capabilities on Indonesian pharmaceutical firms performance. Systematic Reviews in Pharmacy, 11(9), 982-992. https://doi.org/10. 31838/srp.2020.9.142

Denney, R. M., \& Aten, J. D. (2020). Religious coping. In D.A., Leeming, K. Madden, \& S. Marlan (Eds.), Encyclopedia of psychology and religion. Springer. https://doi.org/10.1007/978-0-387-71802-6_578

Djalante, R., Lassa, J., Setiamarga, D., Sudjatma, A., Indrawan, M., Haryanto, B., . . Rafliana, I. (2020). Review and analysis of current responses to COVID-19 in Indonesia: Period of January to March 2020. Progress in Disaster Science, 6, 1-9. https://doi.org/10.1016/j.pdisas.2020.100091

Foroutan, Y. (2019). Cultural analysis of half-century demographic swings of Iran: The place of popular culture. Journal of Ethnic and Cultural Studies, 6(1), 77-89.

French, D. C., Purwono, U., \& Shen, M. (2020). Religiosity and positive religious coping as predictors of Indonesian Muslim adolescents' externalizing behavior and loneliness. Psychology of Religion Spirituality. Advance online publication. https://doi.org/10.1037/ rel0000300

Hair, J. F., Black, W. C., Babin, B. J., \& Anderson, R. E. (2010). Multivariate data analysis: A global perspective (7th ed.). Pearson Prentice Hall. 
Henseler, J., Ringle, C. M., \& Sarstedt, M. (2015). A new criterion for assessing discriminant validity in variance-based structural equation modeling. Journal of the Academy of Marketing Science, 43(1), 115-135. https://doi.org/10.1007/s11747-014-0403-8

Henseler, J., Ringle, C. M., \& Sinkovics, R. R. (2009). The use of partial least squares path modeling in international marketing. In R. R. Sinkovics \& P. N. Ghauri (Eds.), New challenges to international marketing, (Vol. 20, pp. 277-319). Emerald Group Publishing Limited.

Hill, L., \& Nidumolu, P. (2020). The influence of classical Stoicism on John Locke's theory of selfownership. History of the Human Sciences, 34(3-4), 3-24. https://doi.org/10.1177/0952695120910641

Hodge, E. G. (2018). Grievance and responsibility: Emotional motivators and knowledge production networks in men's rights and pro-feminist men's groups in North America [Doctoral dissertation, University of https://dspace.library.uvic.ca//handle/1828/9996

Huecker, M. R. (2020). Stoicism defeats burnout. Academic Emergency Medicine, 27(12), 13741376. https://doi.org/10.1111/acem.13967

Hysa, E. (2020). Impact of cultural diversity on Western Balkan countries' performance. Journal of Ethnic and Cultural Studies, 7(1), 20-40.

Jordan, A. (2020). Thomas carlyle and stoicism. Classical Receptions Journal, 13(2), 212-233. https://doi.org/10.1093/crj/claa008

Katipana, M. V., Wiryana, M., Aryasa, E. T., \& Pradhana, A. P. (2021). Perioperative management in obstetric patients with suspected COVID-19 at Bali, Indonesia: Case series. Online publication. Bali Journal of Anesthesiology, 5(1), 40-44. https://doi.org/10.4103/BJOA.BJOA_166_20

Kaukiainen, A., \& Kõlves, K. (2020). Too tough to ask for help? Stoicism and attitudes to mental health professionals in rural Australia. Rural Remote Health, 20(2), 5399-5399. doi: $10.22605 /$ rrh5399

Li, Y., Wang, Y., Jiang, J., Valdimarsdóttir, U. A., Fall, K., Fang, F., Song, H., Lu, D., \& Zhang, W. (2020). Psychological distress among health professional students during the COVID-19 outbreak. Psychological $\quad$ Medicine, $\quad 51(11), \quad$ 1-3. https://doi.org/10.1017/S0033291720001555

Liu, M. (2019). Predicting effects of demographic, linguistic and psychological variables on university international students' intercultural communication sensitivity. Journal of Ethnic and Cultural Studies, 6(3), 123-133. https://doi.org/10.29333/ejecs/277

Lo, G. T. (2012). Do daily spiritual experiences buffer the effects of Stoicism and fatalism on psychological distress and treatment seeking in a Chinese American cancer sample with pain? (Publication No. 3495892) [Doctoral dissertation, Fordham University]. ProQuest Dissertations Publishing.

Long, K. N., Chen, Y., Potts, M., Hanson, J., \& VanderWeele, T. J. (2020). Spiritually motivated self-forgiveness and divine forgiveness, and subsequent health and well-being among middle-aged female nurses: an outcome-wide longitudinal approach. Online publication. Frontiers in Psychology, 11, 1337. https://doi.org/10.3389/fpsyg.2020.01337

Luczak, C., \& Kalbag, A. (2018). The appropriateness and effectiveness of cross-aged peer mentoring in the learning environment. International Journal of Humanities, Arts and Social Sciences, 4(2), 76-84. https://doi.org/10.20469/ijhss.4.10003-2 
Makhmudov, K. (2020). Ways of forming intercultural communication in foreign language teaching. Science and Education, 1(4), 84-89. https://doi.org/10.6084/m9.figshare.12750647.v1

Maman, Z. S., Chen, Y.-J., Baghdadi, A., Lombardo, S., Cavuoto, L. A., \& Megahed, F. M. (2020). A data analytic framework for physical fatigue management using wearable sensors. Expert Systems with Applications, 155(1), 113405. https://doi.org/10.1016/j.eswa.2020.113405

Manierre, M., Jansen, E., \& Boolani, A. (2020). Sleep quality and sex modify the relationships between trait energy and fatigue on state energy and fatigue. PloS one, 15(1), 1-14. https://doi.org/10.1371/journal.pone.0227511

Mansoor, M. (2021a). Citizens' trust in government as a function of good governance and government agency's provision of quality information on social media during Covid-19. Government Information Quarterly, 101597. https://doi.org/10.1016/j.giq.2021.101597

Mansoor, M. (2021b). An interaction effect of perceived government response on Covid-19 and government agency's use of ICT in building trust among citizens of Pakistan. Transforming Transforming Government: People, Process and Policy. Advance online publication. https://doi.org/10.1108/TG-01-2021-0002

Mansoor, M., \& Noor, U. (2019). Determinants of green purchase intentions: Positive word of mouth as moderator. Journal of Business \& Economics, 11(2), 143-160. http://journals.au.edu.pk/ojs/index.php/jbe/article/view/125/126

Mayer, J. D., \& Lewis, N. D. (2020). An inevitable pandemic: Geographic insights into the Covid19 global health emergency. Eurasian Geography Economics, 61(4-5), 404-422. https://doi.org/10.1080/15387216.2020.1786425

McAteer, G., \& Gillanders, D. (2019). Investigating the role of psychological flexibility, masculine self-esteem and Stoicism as predictors of psychological distress and quality of life in men living with prostate cancer. European Journal of Cancer Care, 28(4). https://doi.org/10.1111/ecc.13097

McElroy-Heltzel, S. E., Van Tongeren, D. R., Gazaway, S., Ordaz, A., Davis, D. E., Hook, J. N., . . Stargell, N. A. (2018). The role of spiritual fortitude and positive religious coping in meaning in life and spiritual well-being following Hurricane Matthew. Journal of Psychology Christianity, 37(1), 17-27.

Mediastari, A. A. P. A. (2020). Local wisdom traditional medicine for the health and beauty of postpartum mother in Denpasar City, Bali Province, Indonesia. International Journal of Health Medical Sciences, 3(1), 65-71. https://doi.org/10.31295/ijhms.v3n1.149

Miconi, D., Li, Z. Y., Frounfelker, R. L., Santavicca, T., Cénat, J. M., Venkatesh, V., \& Rousseau, C. (2021). Ethno-cultural disparities in mental health during the Covid-19 pandemic: A cross-sectional study on the impact of exposure to the virus and Covid-19-related discrimination and stigma on mental health across ethno-cultural groups in Quebec (Canada). BJPsych Open, 7(1). https://doi.org/10.1192/bjo.2020.146

Missel, M., Bernild, C., Dagyaran, I., Christensen, S. W., \& Berg, S. K. (2020). A Stoic and altruistic orientation towards their work: A qualitative study of healthcare professionals' experiences of awaiting a COVID-19 test result. BMC health services research, 20(1), 1-9. https://doi.org/10.1186/s12913-020-05904-0

Nedal, O. A., \& Alcoriza, M. G. O. (2018). Challenges in education: The untold story of students in Lanao Kapanglao, Glan, Sarangani province. Journal of Advances in Humanities and Social Sciences, 4(3), 118-126. https://doi.org/10.20474/jahss-4.3.1 
Noor, U., Mansoor, M., \& Rabbani, S. (2021). Brand hate and retaliation in Muslim consumers: does offensive advertising matter? Journal of Islamic Marketing. Advance online publication. https://doi.org/10.1108/JIMA-10-2020-0316

Olebe, M., \& Koester, J. (1989). Exploring the cross-cultural equivalence of the behavioral assessment scale for intercultural communication. International Journal of Intercultural Relations, 13(3), 333-347. https://doi.org/10.1016/0147-1767(89)90016-3

Pandey, J., \& Singh, M. (2019a). Positive religious coping as a mechanism for enhancing job satisfaction and reducing work-family conflict: A moderated mediation analysis. Journal of Management, $\quad$ Spirituality Religion, $\quad$ 16(3), 314-338. https://doi.org/10.1080/14766086.2019.1596829

Pargament, K. I., Koenig, H. G., \& Perez, L. M. (2000). The many methods of religious coping: Development and initial validation of the RCOPE. Journal of Clinical Psychology, 56(4), 519-543. https://doi.org/10.1002/(sici)1097-4679(200004)56:4<519::aid-jclp6>3.0.co;2-1

Pathak, E. B., Wieten, S. E., \& Wheldon, C. W. (2017). Stoic beliefs and health: Development and preliminary validation of the Pathak-Wieten Stoicism Ideology Scale. BMJ Journals, 7(11), 1-9. https://doi.org/10.1136/bmjopen-2016-015137

Putra, N. H., Sutarto, J., \& Yusuf, A. (2021). Influence of organizational climate towards polyglot Indonesia members intercultural communication skill mediated by self motivation. Journal of Nonformal Education, 7(1), 14-22. https://doi.org/10.15294/jne.v7i1.26790

Qiu, J., Shen, B., Zhao, M., Wang, Z., Xie, B., \& Xu, Y. (2020). A nationwide survey of psychological distress among Chinese people in the Covid-19 epidemic: Implications and policy recommendations. General psychiatry, 33(2). https://doi.org/10.1136/gpsych-2020100213

Rahiem, M., \& Rahim, H. (2020). The sultan and the soup: A Javanese cultural response to COVID19. Journal of Ethnic and Cultural Studies, 8(1), 43-65.

Ramos-Roure, F., Feijoo-Cid, M., Manresa-Dominguez, J. M., Segura-Bernal, J., García-Sierra, R., Fernández-Cano, M. I., \& Toran-Monserrat, P. (2021). Intercultural communication between long-stay immigrants and Catalan primary care nurses: A qualitative approach to rebalancing power. International Journal of Environmental Research and Public Health, 18(6), 2851. https://doi.org/10.3390/ijerph18062851

Sadeghi, S., Sajjadi, S. N., Nooshabadi, H. R., \& Farahani, M. J. (2018). Social-cultural barriers of Muslim women athletes: Case study of professional female athletes in Iran. Journal of Management Practices, Humanities and Social Sciences, 2, 6-10. https://doi.org/10.33152/jmphss-2.1.2

Sastry, S., \& Ramasubramanian, S. (2020). The subcontinent speaks: Intercultural communication perspectives from/on South Asia. Taylor \& Francis.

Sawatsuk, B., Darmawijaya, I. G., Ratchusanti, S., \& Phaokrueng, A. (2018). Factors determining the sustainable success of community-based tourism: Evidence of good corporate governance of Mae Kam Pong Homestay, Thailand. International Journal of Business and Economic Affairs, 3(1), 13-20. https://doi.org/10.24088/IJBEA-2018-31002

Scoats, R., \& Robinson, S. (2020). From stoicism to bromance: Millennial men's friendships. In R. Magrath, J. Cleland \& E. Anderson (Eds), The Palgrave Handbook of Masculinity and Sport (pp. 379-392). Springer.

Shanks, T. (2019). The rhetoric of self-ownership. Political Theory, 47(3), 311-337. https://doi.org/10.1177/0090591718786471 
Sharma, S., \& Singh, K. (2019). Religion and well-being: The mediating role of positive virtues. Journal of Religion Health, 58(1), 119-131. https://doi.org/10.1007/s10943-018-0559-5

Silver, J. R. (2017). Moral foundations, intuitions of justice, and the intricacies of punitive sentiment. Law Society Review, 51(2), 413-450. https://doi.org/10.1111/lasr.12264

Singaram, V. S., \& Saradaprabhananda, S. (2020). Cultural thanatology: An exploration of the religious, spiritual, and existential concerns of elderly terminally-ill diasporic Hindus. Journal of Religion, Spirituality Aging, 33(3), 311-331. https://doi.org/10.1080/15528030.2020.1757011

Smrcz, Á. (2017). A Neo-Stoic theory of natural and unnatural affections. In G. Boros, J. Szalai \& O. I. Toth (Eds.), The concept of affectivity in early modern philosophy (pp. 11-23). Eötvös Loránd University.

Táíwò, O. m. O. (2020). Stoicism (as emotional compression) is emotional labor. Feminist Philosophy Quarterly, 6(2), 1-25. https://doi.org/10.5206/fpq/2020.2.8217

Taylor, T. S., Raynard, A. L., \& Lingard, L. (2019). Perseverance, faith and Stoicism: a qualitative study of medical student perspectives on managing fatigue. Medical Education, 53(12), 1221-1229. https://doi.org/10.1111/medu.13998

Thomas, J., \& Barbato, M. (2020). Positive religious coping and mental health among Christians and Muslims in response to the COVID-19 pandemic. Religions, 11(10), 498-511. https://doi.org/10.3390/rel11100498

Wade, J. C., Suryani, L. K., \& Lesmana, C. B. J. (2018). Religiosity, masculinity, and marital and life satisfaction among Balinese Hindu men. International Journal of Research Studies in Psychology, 7(1), 99-114. https://doi.org/10.5861/ijrsp.2018.3006

Wagstaff, G. F., \& Rowledge, A. M. (1995). Stoicism: Its relation to gender, attitudes toward poverty, and reactions to emotive material. The Journal of Social Psychology, 135(2), 181184. https://doi.org/10.1080/00224545.1995.9711421

Warbinton, E. (2019). Mental health in rural areas: To what extent do Stoicism, stigma, and community affiliation predict mental health help-seeking behaviors? [Doctoral dissertation, The University of Okalhama]. https://shareok.org/bitstream/handle/11244/319917/2018_Warbinton_Erika_Dissertation.p $\mathrm{df}$ ? sequence $=5$ \&isAllowed $=\mathrm{y}$

Yamamori, K. (2019). Classroom practices of low-cost STEM education using scratch. Journal of Advanced Research in Social Sciences and Humanities. 4(6), 192-198. https://dx.doi.org/10.26500/JARSSH-04-2019-0601

Yanti, E. D., Pradiksa, H., \& Susiladewi, I. A. M. V. (2021). Nurses knowledge and perception regarding personal protective equipment while caring for patients with Covid-19. Jurnal Keperawatan, 13(1), 213-226. https://doi.org/10.32583/keperawatan.v13i1.1162

Zhang, J., Lu, H., Zeng, H., Zhang, S., Du, Q., Jiang, T., \& Du, B. (2020). The differential psychological distress of populations affected by the Covid-19 pandemic. Online publication. Brain, Behavior, and Immunity, 87, 49-50. https://doi.org/10.1016/j.bbi.2020.04.031 


\section{Notes on Contributors}

A. Akrim is deputy rector II of Universitas Muhammadiyah Sumatera Utara and also a lecturer in the Department of Islamic Religion Education, Faculty of Islamic Religious. He received an undergraduate degree (S.Pd) in education from the University of Muhammadiyah Sumatra Utara in 2003 and a Master degree (M.Pd) also in education obtained from Universitas Negeri Medan in 2008 and a Doktor degree (Dr) also in Islamic Religion Education from Muhammadiyah University of Malang in 2020. His main research field is education especially Islamic religious education and early childhood education.

Rudianto is deputy rector III of Universitas Muhammadiyah Sumatera Utara and also a lecturer in the Department of communication, Postgraduate Universitas Muhammadiyah Sumatera Utara. He received an undergraduate degree (S.Sos) in communication from the University of Muhammadiyah Sumatera Utara in 1999 and a Master degree (M.Si) also in communication from Padjajaran University of Bandung in 2005 and a Doktor degree (Dr) also in communication from Padjajaran University of Bandung in 2017. His main research field is communication especially Cultural Communication and Political Communication.

Abrar Adhani is deputy dean III of Faculty of Social Science and Politic Universitas Muhammadiyah Sumatera Utara and also a lecturer in the Department of communication. He received an undergraduate degree (S.Sos) in communication from the University of Muhammadiyah Sumatra Utara in 2002 and a Master degree (M.Si) also in communication from Muhammadiya University of Jakarta in 2011. His main research field is communication especially Cultural Communication and Bussines communication. 